\title{
ADVERSE SELECTION IN INSURANCE MARKETS: POLICYHOLDER EVIDENCE FROM THE U.K. ANNUITY MARKET
}

\author{
Amy Finkelstein \\ James Poterba \\ Working Paper 8045 \\ http://www.nber.org/papers/w8045 \\ NATIONAL BUREAU OF ECONOMIC RESEARCH \\ 1050 Massachusetts Avenue \\ Cambridge, MA 02138 \\ December 2000
}

We are grateful to Jeffrey Brown, Jerry Hausman, Michael Orszag, Richard Zeckhauser, and participants at the MIT Econometrics and Public Finance workshops and the NBER Aging Summer Institute for helpful suggestions, and to Jason Abrevaya for providing us with GAUSS code. We are especially grateful to the employees of the U.K. insurance company who generously provided us with the data used in this paper and answered many questions about it. The National Science Foundation and the National Institute of Aging supported this research. The views expressed in this paper are those of the authors and not necessarily those of the National Bureau of Economic Research.

(C) 2000 by Amy Finkelstein and James Poterba. All rights reserved. Short sections of text, not to exceed two paragraphs, may be quoted without explicit permission provided that full credit, including $\mathbb{C}$ notice, is given to the source. 
Adverse Selection in Insurance Markets: Policyholder Evidence

from the U.K. Annuity Market

Amy Finkelstein and James Poterba

NBER Working Paper No. 8045

December 2000

JEL No. D82, G22, H55

\begin{abstract}
This paper presents new evidence on the importance of adverse selection in insurance markets. We use a unique data set, consisting of all annuity policies sold by a large U.K. insurance company since the early 1980s, to analyze mortality differences across groups of individuals who purchased different types of policies. We find systematic relationships between ex-post mortality and annuity policy characteristics, such as whether the annuity will make payments to the estate in the event of an untimely death and whether the payments from the annuity rise over time. These mortality patterns are consistent with models of asymmetric information in insurance markets. We find no evidence of mortality differences, however, across annuities of different size, as measured by the initial annual payment from the annuity. We also study differences in the pricing of different annuity products, and find that the pricing of various features of annuity contracts is consistent with the self-selection patterns we find in mortality rates. Our results therefore suggest that many specific features of insurance contracts can serve as screening mechanisms. This implies that insurance markets may be characterized by adverse selection, even when stratifying policyholders by the amount of payment in case of a claim does not support the existence of selection effects.
\end{abstract}

Amy Finkelstein

Department of Economics, E52

MIT

50 Memorial Drive

Cambridge, MA 02142

and NBER

afink@mit.edu
James Poterba

Department of Economics, E52

MIT

50 Memorial Drive

Cambridge, MA 02142

and NBER

poterba@mit.edu 
Theoretical research on insurance markets has long emphasized the potential importance of asymmetric information. The welfare implications of adverse selection, one of the consequences of asymmetric information, are well documented. Yet several recent empirical papers have failed to find evidence of asymmetric information in property-casualty, life, and health insurance markets. Cawley and Philipson (1999), who study the U.S. life insurance market, Cordon and Hendel (1999), who study the U.S. health insurance market, and Chiappori and Salanie (2000), who study the French automobile insurance market, all find it difficult to reject the null hypothesis of symmetric information. These findings raise new questions about whether asymmetric information is, in practice, an important feature of insurance markets.

This paper tests two simple predictions of asymmetric information models using data from the annuity market in the United Kingdom. The first is that higher risk individuals self-select into insurance contracts that offer features that, at a given price, are more valuable to them than to lower risk individuals. The second is that the equilibrium pricing of insurance policies reflects the fact that the risk pool varies across different policies. Such self-selection across policies by risk type would not occur if the insurer and the insured had symmetric information. Our empirical work finds support for both of these predictions.

Annuity markets are an interesting setting in which to study asymmetric information problems. These markets are of substantial interest in their own right. Mitchell, Poterba, Warshawsky, and Brown (1999) emphasize that annuities, which provide insurance against outliving one's resources, play a potentially important welfare-improving role for retirees. But in spite of the potential value of annuity products for households that face uncertain mortality and have fixed resources, voluntary annuity markets in both the United States and the United Kingdom are small. Asymmetric information, in particular adverse selection, has often been suggested as a potential explanation for the limited size of these markets.

Besides their intrinsic interest, there is another reason for studying asymmetric information issues in the context of annuity markets. Most tests for asymmetric information cannot distinguish between 
adverse selection and moral hazard, even though the welfare implications of the two, and their potential policy implications, are often quite different. Moral hazard seems likely to play a smaller role in annuity markets, however, than in many other insurance markets. While receipt of an annuity may lead some individuals to devote additional resources to life-extension, we suspect that this is likely to be a quantitatively small effect. If the behavioral effects of annuities are small, so that the associated moral hazard problems are limited, testing for asymmetric information in the annuity market provides a particularly valuable test for adverse selection.

This paper is divided into six sections. The first outlines a simple theoretical model of screening and adverse selection. It presents a generalized version of the classic Rothschild-Stiglitz (1976) model to illustrate that when insurance contracts are multi-dimensional, many features of the insurance contract can serve as screening mechanisms. Two empirical predictions of this model form the basis for our empirical tests. This section also summarizes the previous literature that has tested for asymmetric information in insurance markets.

Section two describes the general operation of annuity markets. It notes several specific features of the annuity market in the United Kingdom that are relevant for our analysis. It also refines the model from the first section to apply specifically to the annuity market setting. The third section describes the data set that we have obtained from a large U.K. insurance company, and compares the annuitants at this firm with those in the market at large.

Section four explores the relationship between mortality patterns and annuity product choice. In this section, we develop hazard models that relate the probability of annuitants dying after purchasing annuities to detailed characteristics of the annuity policy, as well as other information about the annuitant that is known to the insurance company. The empirical findings indicate that ex-post annuitant mortality varies systematically across annuity policies with different characteristics. This variation is consistent with theoretical models of asymmetric information.

The fifth section investigates the pricing of different annuity products. We report hedonic pricing models that include different features of annuity policies. We also present some evidence on the pricing 
formula used by the insurance company whose data we analyze. We find that annuity pricing is consistent with the presence of adverse selection in the annuity market. Features of the annuity that our hazard models indicate are selected by low mortality individuals, the "high risk" annuity buyers from the perspective of the insurance company, are priced higher than features that are selected by high-mortality individuals. We do not find evidence that mortality rates differ, or that marginal prices differ, across annuities with different initial annual annuity payment. The initial annual annuity payment is a crude measure of the size of the annuity policy, and it is our best approximation to the "amount of insurance" that features in most theoretical discussions of adverse selection. This finding underscores the importance of considering adverse selection along a range of different insurance policy attributes.

The final section summarizes our findings and considers explanations for our results that might not involve adverse selection.

\section{Adverse Selection and Screening in Insurance Markets: Theory and Evidence}

This section describes the nature of equilibrium in insurance markets in the presence of adverse selection, with particular emphasis on the structure of insurance market prices. The discussion is general; the next section applies the analysis to the annuity market. This section also includes a brief summary of existing empirical research on asymmetric information in insurance markets.

\subsection{Theoretical Background}

The standard model of insurance markets, developed for example in Rothschild and Stiglitz (1976), assumes that there are two types of individuals who differ only in their risk type $p$. The parameter $p$ denotes the probability the individual will incur a claim against the insurance company. We denote these two types of individuals by $p_{H}$ and $p_{L}$, with $p_{H}>p_{L}$. The individual knows his or her risk type, but the insurance company does not. Competition in the insurance market implies a zero profit condition. 
The insurance company offers a menu of insurance contracts with different features. It designs this menu to screen customers according to their risk type. The key to this screening mechanism is that if the value of a contract feature differs across individuals of different risk types, the insurance company can, through appropriate pricing, induce individuals to self-select into different contracts on the basis of their (privately known) risk type. Under symmetric information, in contrast, each individual would purchase the same, efficient, insurance contract and individual-specific prices would reflect individualspecific risk.

In the Rothschild-Stiglitz (1976) framework, insurance contracts differ only in the quantity of insurance sold and the marginal price charged. In this case, the screening equilibrium involves high-risk individuals buying full insurance, as in the symmetric information case. Low-risk individuals buy the maximum amount of insurance that they can purchase while leaving the high-risk individuals indifferent between paying the marginal price $p_{H}$ for full insurance and paying the marginal price $p_{L}$ to buy the amount of insurance purchased by the low-risk individuals. The key to this equilibrium is that the marginal utility that the high risk type gets from an extra unit of insurance at a given price is higher than the marginal utility that the low risk type gets from an extra unit of insurance at this same price. This Spence-Mirlees (or single crossing) property ensures that there exists some quantity of insurance that the low risk type can purchase at marginal price $p_{L}$ that leaves the high risk type indifferent between purchasing this quantity of insurance at price $p_{L}$ and buying full insurance at the higher price $p_{H}$.

It is straightforward to generalize this model to allow for a multi-dimensional vector of insurance product characteristics. Smart (2000) discusses extensions of this type. Any features that satisfy the Spence-Mirrlees condition can potentially be used to separate different risk types into different insurance contracts. The basic result that markets characterized by asymmetric information are inefficient hold regardless of the feature, or features, of insurance contracts that are used to screen customers.

Our empirical tests for asymmetric information in the annuity market are based on two predictions that emerge from models like the one sketched above. Chiappori and Salanie (2000) note that 
these predictions are robust with respect to many modifications of the basic framework. First, there should be a positive correlation between (privately known) risk type and the demand for features of insurance contracts whose marginal value is greater for high-risk types. Second, insurance companies should charge more for features of insurance contracts that are purchased by higher risk types than for features that are purchased by lower risk types.

In practice, the insurance company may observe some risk features of the individual. The stylized model described above therefore applies to individuals who are observationally equivalent to the insurance company, and the foregoing predictions apply conditional on the characteristics of the insured that are observable by the insurance company.

\subsection{Empirical Tests of Asymmetric Information in Insurance Markets}

Several recent papers, linked by a common empirical strategy, have tested for adverse selection in insurance markets. These papers examine the relationship between ex-post risk type and insurance coverage, conditional on observable characteristics of individuals. Models of asymmetric information predict a positive relationship between risk type and the amount of insurance coverage, if the amount of insurance coverage is used as a screening device. Pueltz and Snow (1994) test this relationship in the U.S. automobile insurance market. They find that higher risk individuals, measured by ex-post accident probabilities, choose policies with lower deductibles, and hence greater insurance coverage. This finding is consistent with the presence of asymmetric information.

Several other recent studies reach a different conclusion, using data from different insurance markets. Chiappori and Salanie (2000) also examine automobile insurance markets, using data from France. They relate both quantity of insurance and ex-post risk type to exogenous variables, and then test for a positive correlation between the errors of the two estimating equations. They cannot reject the null hypothesis that the two sets of residuals are uncorrelated. Using a similar test, Cordon and Hendel (1999) fail to reject the null hypothesis of symmetric information in health insurance markets. In a related study, Cawley and Philipson (1999) examine the relationship between insurance coverage and risk in the U.S. 
life insurance market. Their results also fail to reject the null hypothesis that risk type and amount of insurance coverage are uncorrelated.

The preponderance of recent research fails to reject the null hypothesis of symmetric information in insurance markets. One common limitation of these studies is their focus on a one-dimensional screening variable: the amount of payment in the event of an accident. Chiappori and Salanie (2000) acknowledge that there are "many different comprehensive coverage contracts on offer," but they focus on a binary measure of whether the individual has anything more than the legal minimum level of coverage. Cawley and Philipson (1999) examine the relationship between risk type and the amount the term insurance policy would pay out in the event of death, while ignoring other potential screening variables such as the renewability of a life insurance policy. In practice, many aspects of insurance contracts may satisfy the Spence-Mirrlees condition and therefore have the potential to serve as screening mechanisms. We emphasize this, and try to fashion appropriate empirical tests, in our subsequent analysis. While we do not find any evidence of screening on the amount of payment that the insurance policy prescribes, we do find evidence of asymmetric information using other screening devices.

Several of these studies also test our second empirical prediction that features of insurance that are selected by higher risk individuals should be priced correspondingly higher. This involves, at a general level, testing the prediction that insurance policies with more comprehensive coverage sell at higher marginal prices. Pueltz and Snow (1994) find a concave premium-deductible schedule, which suggests that low risk individuals, who choose large deductibles, receive lower marginal prices for their choice. Cawley and Philipson (1999), however, find no evidence that the marginal price of insurance rises with the amount of payment of the event of death. This is consistent with their finding of a lack of correlation between risk type and amount of insurance coverage. 


\section{Background on Annuities and Annuity Markets}

This section presents an overview of the annuity market in the United Kingdom. It then applies the framework developed in the last section to this market, and formalizes the model-based predictions that underpin our empirical work.

\subsection{Annuity Market Overview}

An annuity is a contract that pays a pre-specified amount to a beneficiary, the annuitant, for as long as the annuitant is alive. It thus insures the annuitant against the risk of outliving his accumulated resources. In some ways annuities function as reverse life insurance, insuring against the risk of living too long rather than against the risk of dying too soon. From the standpoint of an annuity insurance company, a high-risk individual is an individual who is likely to live longer than his observable attributes, such as age, would otherwise suggest.

Yaari (1965) documented the welfare-improving role of annuity insurance for individuals facing uncertain mortality. In light of this, the small size of the voluntary annuity market in the United States and the United Kingdom has puzzled many researchers. One possible explanation for the small market size is adverse selection. A number of previous studies suggest that annuity markets are characterized by some adverse selection. The pricing of voluntary annuities in both the U.S. and the U.K. implies that, for a typical individual from the population, the expected present discounted value of the payments from an annuity are only 80 to 85 percent of the annuity's initial premium. Part of the divergence between this expected payout and the cost of the annuity is due to administrative loads, but roughly half appears to be due to adverse selection. If the typical annuitant is longer lived than the typical individual drawn at random from the population, then annuities priced to reflect the longevity of the annuitant population will not be actuarially fair for the typical individual in the population. Indeed, market-wide mortality tables published in the U.S. and the U.K. based on the mortality experience of voluntary annuitants suggest that 
the typical voluntary annuitant 65 -year-old male is expected to live twenty percent longer than the typical 65-year-old male in the population. ${ }^{1}$

While these mortality patterns are consistent with adverse selection into the annuity market, they do not provide evidence on a relationship between mortality rates and the type of annuity purchased by annuitants. We are not aware of any published mortality tables that distinguish annuitants by the type of annuity policy that they purchase. Yet this relationship is the central prediction of asymmetric information models of insurance markets. The data in this paper allow a direct investigation of this relationship.

The U.K. annuity market provides a particularly rich setting for studying adverse selection in annuity markets. There are effectively two annuity markets in the United Kingdom. There is a compulsory annuity market in which individuals who have accumulated savings in tax-preferred retirement vehicles similar to 401(k)'s or IRA's in the U.S. are required to annuitize a large portion of their accumulated balance. There is also a voluntary annuity market in which individuals with accumulated savings may use these accumulated assets to purchase an annuity. Finkelstein and Poterba (1999) suggest that adverse selection, as measured by the average price of annuity contracts, is roughly half as great in the compulsory market as in the voluntary market.

A wide variety of annuity products are sold in both the compulsory and voluntary annuity markets. Annuitants in the compulsory market face virtually no restrictions on the types of annuities that they can purchase. This suggests that there is scope for selection among annuity products in both markets. We focus our analysis on annuities that pay a pre-determined payment stream. We also limit our analysis to annuities that insure a single life, as opposed to joint life annuities that continue to pay out as long as one of several annuitants remains alive.

We pay particular attention to three features of annuity policies that may serve as screening devices. One is the initial annual annuity payment. The payment amount is the analog of the payment in

\footnotetext{
${ }^{1}$ Finkelstein and Poterba (1999) and Murthi, Orszag, and Orszag (1999) present summary information and mortality comparisons for the U.K. annuity market. Brown, Mitchell, and Poterba (2000), and Poterba and Warshawsky (2000), present related information for the U.S. market.
} 
the event of accident in the auto insurance market. It is a rough measure of the amount of insurance purchased by the annuitant.

A second annuity feature that we consider is the tilt, or degree of backloading. A more backloaded annuity is one with a payment profile that provides a greater share of payments in later years. The most common form of annuity is a nominal annuity, which pays out a constant nominal amount each period. In a world with positive expected inflation, the expected real payment stream from such an annuity is declining over time. An escalating annuity, in contrast, provides a payment stream that rises at a pre-specified nominal rate in each year. Annuities escalate at a nominal rate of anywhere from $3 \%$ to $8.5 \%$ in our data. These escalating annuities may be rising in real terms depending on the expected rate of inflation. There are also real (i.e. inflation-indexed) annuities, which pay out a constant real amount in each year. The payments from real annuities and from escalating annuities are both backloaded relative to those from nominal annuities.

A third feature that we focus on is whether the annuity may make payments to the annuitant's estate. Some annuities offer guarantee periods. The insurance company continues to make payments to the annuitant's estate for the duration of the guarantee period even if the annuitant dies before the guarantee period expires. Annuities with guarantee periods of one to fifteen years are present in our data sample, although in the compulsory market, regulations forbid the sale of policies with guarantee periods of more than ten years. "Capital protection" is another form of potential payments to the estate. If at the date of the annuitant's death the sum of nominal annuity payments to date is less than the premium paid for the annuity, a capital-protected annuity pays the difference to the estate as a lump sum.

All three of these features -- initial payment amount, backloading, and the presence of payments to the estate -- are potential screening devices for insurance companies with less information than their customers. Our empirical work explores whether the annuitants who choose these different features differ in their mortality experience and whether the pricing of these different features reflects any such mortality differences across features. 


\subsection{Market Equilibrium in the Annuity Market}

To apply the equilibrium framework discussed in the last section to the annuity market, we represent an annuity contract by a vector $x=(a, \tau, g)$. The initial annuity payment is $a, \tau$ denotes the tilt or backloading of the annuity payout stream, and $g$ denotes the guaranteed payout amount. We consider a two-period setting, in which an individual of risk type $i$ has a probability of surviving in each period of $p_{i}$. Individuals purchase insurance contracts at the beginning of the first period. They then learn if they will survive through the first period, in which case they will receive their annuity payout. If they survive through the second period as well, they receive annuity payouts in both periods. For simplicity, we prohibit saving between the first and second period, and we assume a zero discount rate. We further assume that guaranteed payouts are paid to the annuitant's estate, and that they are only paid, if at all, in the period when the annuitant dies.

The expected utility of individual of risk type $\mathrm{i}$ who purchases policy $x$ is therefore:

(1) $V_{i}\left(p_{i}, g_{t}, \tau, a\right)=\left(1-p_{i}\right) U\left(g_{1}\right)+p_{i} U(a)+p_{i}^{2} U(a(1+\tau))+\left(1-p_{i}\right) p_{i} U\left(g_{2}\right)$.

With probability $\left(1-p_{i}\right)$, individual i dies in the first period and his estate receives the amount guaranteed if he dies in the first period, $g_{1}$. With probability $p_{i}$ individual i survives the first period and receives initial annual annuity payment $a$. He then survives to the second period with probability $p_{i}^{2}$, in which case he then receives an annuity payment of $a(1+\tau)$, where $\tau$ denotes the tilt factor. Finally, with probability $\left(1-\mathrm{p}_{\mathrm{i}}\right) \mathrm{p}_{\mathrm{i}}$ the individual survives the first period but dies in the second period. In this case, the annuitant's estate receives the second period guaranteed payment of $g_{2}$.

Screening on a given annuity characteristic requires that the Spence-Mirrlees property be satisfied for that characteristic. Equation (1) indicates that the marginal value of the initial annual annuity payment (a) is increasing in risk type $p$ as is the marginal value of an increase in tilt $(\tau)$. Finally, the marginal value of a guaranteed payout $(\mathrm{g})$ is decreasing in $p$. Thus all three features satisfy the Spence-Mirlees property and are therefore potential screening devices. 
These results have an intuitive interpretation. The initial annual annuity payment is the analog of the payment in the event of a claim, or "quantity" in the Rothschild and Stiglitz (1976) model. The analysis of screening on this variable therefore follows the earlier discussion of screening on quantity choice in that model. An annuity with an upward tilt has more of its payments in later periods than an annuity with a flat payment profile. An annuitant with a longer life expectancy is more likely to be alive in later periods when the tilted annuity pays out more than the flat annuity. Such an annuitant therefore expects to gain more, at a given price, from a tilted annuity than does an annuitant with a shorter life expectancy. Similarly, an annuity that pays out more in the event of an early death, either with a guarantee period or with capital protection, is of greater value to an individual who is shorter lived than to one who is longer lived.

This model makes several predictions about the relative mortality patterns of different annuitants, if the annuity market is characterized by asymmetric information. For example, individuals who buy more backloaded annuities should be longer lived, conditional on observables, than those who buy less backloaded policies. In a similar fashion, those who buy annuities that make payments to the estate should be shorter-lived, and that those who buy annuities with larger initial annual payments should be longer lived, conditional on observables.

The foregoing model also makes predictions with respect to the pricing of annuity contracts. More backloaded annuities and annuities with larger initial annuity payments should be priced higher to reflect the fact that in equilibrium they are purchased by longer lived individuals than the buyers of other annuities. Similarly, annuities that make payments to the annuitant's estate should be priced lower to reflect the fact that in equilibrium they are purchased by shorter-lived individuals.

Table 1 summarizes our predictions with respect to pricing and mortality patterns in the annuity market when there is adverse selection. These predictions would not obtain in a setting with symmetric information. Consider the case of the degree of backloading of the annuity. With symmetric information, a longer-lived annuitant has no incentive to buy an annuity with backloaded payments. Whatever annuity he buys, the insurance company will adjust the price charged to reflect his individual mortality prospects. 
Since the price adjusts, any preference for an annuity of a given tilt will be influenced only by discount rates, not by mortality prospects. When the annuitant has private information that he is likely to be longlived, however, when he chooses to buy a particular annuity the price is not fully adjusted to take account of his mortality prospects. The key difference between the symmetric and asymmetric information scenarios is that under asymmetric information, the annuitant acts as a price taker, while under symmetric information, he does not. With asymmetric information, the price of a backloaded annuity will reflect the average mortality prospects of the annuitants who, in equilibrium, purchase backloaded annuities. This price will not reflect an individual annuitant's mortality prospects.

We test for asymmetric information in the annuity market by considering both mortality patterns and annuity prices. The fact that in practice, unlike in the stylized model, individuals differ on dimensions other than simply their risk type does not pose a problem for the interpretation of our empirical analysis. If product choice is driven not by private information about mortality but rather by (privately known) preference parameters such as discount rates, risk aversion, or bequest motives which are correlated with mortality, the effect of such private information is similar to the effect of private mortality information. Anything that is correlated with mortality and is known by the individual but not to the insurance company, even if the individual does not recognize its effect on his mortality, operates just like traditional asymmetric mortality information. A potential annuitant's wealth may operate in just this way: higher wealth annuitants are likely to face lower mortality risks, but insurance companies are not aware of the total wealth of their annuity buyers.

\section{Data and Descriptive Statistics}

Our data set consists of information on the complete set of both compulsory and voluntary immediate annuities sold by a large U.K. annuity company over a seventeen-year period ending on December 31, 1998. The first year in our sample, 1981, was the first year when the company sold both voluntary and compulsory annuities. At the end of the sample period, the firm was among the ten largest 
U.K. sellers of new compulsory annuities. ${ }^{2}$ The company's sales mix between compulsory and voluntary annuities shifts within our sample, with sales in the compulsory market growing more rapidly than sales in the voluntary market. This in part reflects the expansion in the late 1980 s of the set of retirement savings plans that face compulsory annuitization requirements. In recent years, sales of voluntary annuities have been a small share of the company's total annuity sales.

Our data set includes almost everything that the insurance company knows about its annuitants. The only pieces of information that we did not receive from the company were the annuitant's address and his or her birthday. This information was suppressed to protect the confidentiality of the annuitants' identities. We did, however, obtain information on the annuitants' birth month. We have information on the type of policy purchased by the annuitant, and on the annuitant's day of death, if the annuitant died within the sample period. Death records are current through December 31, 1998. The insurance company collects very little information - only age and gender - about the personal characteristics of annuitants. In particular, it does not collect any information on the annuitants' wealth, income, education, occupation, or another other indicators of socioeconomic status. The information collection practices at the firm we study are typical for insurance companies selling annuities in the U.K.

We restrict our attention to single life annuities, annuities whose payments are based on the mortality of one individual, because the mortality patterns of the single insured lives on each policy provide a straightforward measure of ex-post risk type. Brown and Poterba (2000) note that it is considerably more complicated to analyze the joint mortality patterns of couples with joint life annuities than to analyze the mortality pattern for a single annuitant. Our final sample size is 42,054 annuity policies.

Table 2 provides an overview of the characteristics of the compulsory and voluntary annuities sold by the company that we analyze. The voluntary market accounts for about one tenth of the policies in our sample, and a somewhat higher fraction of premiums. The relative magnitudes of the voluntary

\footnotetext{
${ }^{2}$ Information on the market share of various U.K. insurance companies in the annuity market may be found at http://insider.econ.bbk.ac.uk/pensions/annuities/experiences/uk/q97s.htm
} 
and compulsory market sales for our sample company are similar to those reported by the Association of British Insurers (various years) for the aggregate U.K. market. Differences between voluntary and compulsory annuitants in our data sample also appear typical of the U.K. market as a whole. Table 2 shows that voluntary annuitants are substantially older than compulsory annuitants. They are also more likely to be female. This is consistent with tabulations from the Family Resources Survey reported in Banks and Emmerson (1999). The product mix of annuities sold by our sample firm also matches the limited aggregate data that exist on the product mix for the U.K. market as a whole. Index-linked and escalating products together make up less than $10 \%$ of the voluntary or the compulsory market, with index-linked policies less than 5\% in each market. Murthi, Orzsag, Orszag (1999) report a similar preponderance of nominal annuities in a data set that includes all insurance companies selling annuities in the United Kingdom.

The modal policy in the compulsory annuity market for 1997 and 1998, when annuity sales peaked for our sample firm, was a nominal annuity with a five-year guarantee period sold to a 65-year-old man. In the voluntary market, the modal policy in 1984 and 1985, which together account for more than one quarter of the voluntary annuity sales in the sample, was a nominal annuity with no guarantee, sold to a 74-year-old woman. These differences underscore the distinct character of the compulsory and voluntary annuity markets.

\section{Annuitant Mortality and Annuity Product Choice}

To test the predictions of asymmetric information models regarding the relationship between insurance product choice and risk type, we estimate hazard models for the mortality experience of annuitants who purchase different types of annuities. This section presents our empirical findings on this issue. In the next section, we investigate whether the variation in prices across different types of annuities accords with the estimated mortality differences. 


\subsection{A Hazard Model Framework for Studying Annuitant Mortality}

We estimate mortality differences among different groups of annuitants using the discrete-time, semi-parametric, proportional hazard model used by Meyer (1990) and Han and Hausman (1990). Our duration measure is the length of time the annuitant lives after purchasing an annuity. We let $\lambda\left(t, x_{i}, \beta, \lambda_{0}\right)$ denote the hazard function, the probability that an annuitant with characteristics $x_{i}$ dies $\mathrm{t}$ periods after purchasing the annuity, conditional on living until t.

The proportional hazard model assumes that $\lambda\left(t, x_{i}, \beta, \lambda_{0}\right)$ can be decomposed into a baseline hazard $\lambda_{0}(t)$ and a "shift factor" $\phi\left(x_{i}, \beta\right)$ as follows:

$$
\lambda\left(t, x_{i}, \beta, \lambda_{0}\right)=\phi\left(x_{i}, \beta\right) \lambda_{0}(t)
$$

The baseline hazard, $\lambda_{0}(t)$, is the hazard when $\phi(\cdot)=1 . \phi(\cdot)$ represents the proportional shift in the hazard caused by the vector of explanatory variables $x_{i}$ with unknown coefficients $\beta$. The proportional hazard model in (2) restricts the effects of the explanatory variables $\left(x_{i}\right)$ to be duration-independent.

We adopt one of the common functional forms for $\phi(\cdot), \phi\left(x_{i} ; \beta\right)=\exp \left(x_{i}^{\prime} \beta\right)$. The proportional hazard model is then written as:

$$
\lambda\left(t, x_{i}, \beta, \lambda_{0}\right)=\exp \left(x_{i}^{\prime} \beta\right) \lambda_{0}(t)
$$

Specification of the baseline hazard $\lambda_{0}(t)$ is a key issue in estimating models like (3). We model the baseline hazard non-parametrically as a step function. This allows us to avoid imposing any restrictive functional form assumptions on the baseline hazard. We have seventeen years of data and we allow for

seventeen, annual, discrete, time periods. If we let $\delta_{t}=\int_{0}^{t} \lambda_{0}(s) d s$ denote the integrated baseline hazard, the proportional hazard model in (3) becomes:

$$
\lambda\left(t_{i} ; x_{i}, \beta, \delta\right)=1-\exp \left\{\exp \left(x_{i}^{\prime} \beta\right)\left(\delta_{t}-\delta_{t+1}\right)\right\} .
$$


Models in which the hazard function is given by (4) can be estimated by maximum likelihood with the log likelihood function given by

$$
\ln (L)=\sum_{i=1}^{n}\left(1-c_{i}\right) \ln \left(\lambda\left(t_{i} ; x_{i}, \beta, \alpha\right)\right)-\int_{0}^{t} \lambda\left(s_{i} ; x_{i}, \beta, \alpha\right) d s
$$

where $\mathrm{c}$ is an indicator variable that equals 1 if the individual survives until the end of our sample period and 0 otherwise. Eighty-four percent of the voluntary annuitants in our sample, and 47 percent of the compulsory annuitants, survive until the end of our sample.

We also estimate hazard models that account for unobserved heterogeneity across individuals. Such heterogeneity can be modeling by assuming that there is an unobserved regressor that is a proportional shifter of the baseline hazard, just like the observed $x_{i}$ regressors. In this case, we rewrite the proportional hazard function in (3) as

$$
\lambda\left(t ; x_{i}, \beta, \alpha, v_{i}\right)=v_{i} \exp \left(x_{i}^{\prime} \beta\right) \lambda_{0}(t ; \alpha)
$$

where $v_{i}$ summarizes the effect of omitted regressors for individual i. We assume a functional form for the probability density function for $v_{i}$ and we then integrate it out of the conditional density function above to obtain a marginal density function. We assume that $v_{i}$ follows a gamma distribution with unit mean and variance $\sigma^{2}$, which is independent of $x_{i}$ and $t$. This assumption implies that the density of $v_{i}$ is proportional to $v^{\sigma^{-2}-1} \exp \left(-v \sigma^{-2}\right)$. This density is chosen mainly for its convenient mathematical form, for it admits an analytical expression for the marginal hazard function:

$$
\lambda\left(t ; x_{i}, \beta, \alpha\right)=\frac{\exp \left(x_{i}^{\prime} \beta\right) \lambda_{0}(t ; \alpha)}{1+\sigma^{2} \exp \left(x_{i}^{\prime} \beta\right) \int_{0}^{t} \lambda_{0}(s) d s} .
$$

When we allow for unobserved heterogeneity in the population, our results are based on maximizing (5) using the definition in (7). Allowing for heterogeneity requires that we estimate one more parameter than in the no-heterogeneity case; this parameter is $\sigma^{2}$. 
We estimate hazard models for annuitant deaths as a function of all of the known characteristics of the annuitants and their annuity policies. Our hazard models do not include any measure of "marginal price" because all of the known characteristics of the annuity product and the annuitant, which are in the models, should completely determine both the policy premium and the marginal price. We estimate separate models for annuitants in the voluntary and compulsory markets. In all of the hazard models we include indicator variables for the age at purchase of the annuity (in five-year intervals), the year of purchase of the annuity, and the gender of the annuitant. We also include indicator variables for the frequency of annuity payments (monthly, termly, quarterly, semi-annually or annually).

We include two indicator variables to capture the degree of backloading of the annuity payment. One is an indicator for whether the annuity payments are indexed to inflation, and the other is an indicator for whether the annuity payments are escalating in nominal terms. Level nominal annuities are the omitted category. The theory described above suggests that individuals who buy index-linked or escalating annuities should be longer lived than those who buy nominal annuities. They should therefore have a lower hazard and so the predicted coefficients on the indicator variables for "index-linked" and for "escalating" in the hazard model are negative. We cannot predict the relative magnitude of these two coefficients, since the choice that a long-lived individual would make between an escalating and an indexed annuity will depend on the rate of expected inflation and the individual's discount rate.

We also include two indicator variables to capture payments to the estate. One is for whether the annuity is guaranteed, and the other is for whether the annuity is capital protected. An annuity cannot be both guaranteed and capital protected. The omitted category is an annuity that does not make any payments to the estate. The theory described above predicts that individuals who buy annuities with more payments to the estate will be shorter-lived (i.e. have a higher hazard rate) than individuals who buy annuities that do not make any payments to the estate. The predicted coefficients on the indicator variables for "guaranteed" and "capital protected" in the hazard model are therefore positive. There is no prior prediction concerning the relative longevity of guaranteed and capital protected annuitants, as there 
is no clear measure of which is relatively more attractive to someone with mortality that diverges from the population average. Thus there is no prediction about the relative size of their coefficients.

Finally, we include one other annuity product characteristic that satisfies the single crossing property and is therefore a potential screening device: the initial annual annuity payment. This "payment" variable corresponds to the amount that would be paid out in life insurance in the event of death or the amount that would be paid out from an automobile insurance policy in the event of an accident. The theory described above predicts that individuals who face greater payments in the event of a claim will be longer lived than individuals who f ace smaller payments in the event of a claim. The predicted coefficient on the "payment" variable in the hazard model is therefore negative. Table 1 summarizes these predictions in columns one and two.

\subsection{Basic Results: Annuity Choice and Mortality Patterns}

Table 3 presents estimates of the hazard model in equation (4). The first column presents estimates from the compulsory annuity market, while the second column presents estimates from the voluntary market. The results closely match our theoretical predictions of self-selection under asymmetric information. In both the compulsory and the voluntary market, there is strong evidence that individuals who buy more backloaded annuities are longer-lived. The coefficients on indicator variables for index-linked and escalating annuities are negative and statistically significant at the $1 \%$ level in both markets, indicating that all else equal, individuals who buy these annuities have a lower mortality hazard rate than individuals who buy nominal annuities.

There is also evidence strong evidence that voluntary annuitants who buy annuities that make payments to the estate in the event of an early death are shorter lived than individuals whose annuities do not make such payments. The coefficient on the indicator variable for guaranteed payouts is positive, indicating that individuals who buy guaranteed annuities have higher hazards (and hence are shorterlived) than observationally similar individuals who buy non-guaranteed, non-capital protected annuities. This coefficient is statistically significantly different from zero at the $1 \%$ confidence level in the voluntary market. Additionally, the coefficient on the indicator variable for a capital-protected annuity is 
positive in the voluntary market, indicating that individuals who buy these annuities are shorter lived than observationally similar individuals who buy non-guaranteed, non-capital protected annuities. The coefficient on the indicator variable for capital protected annuities is not significantly different from zero in our basic specifications, but once we allow for unobserved heterogeneity, it is.

In the compulsory market, the results in Table 3 indicate that although individuals who buy guaranteed annuities are shorter lived than individuals who buy non-guaranteed annuities, the difference in hazard rates is not statistically significant. However, in results not reported here we grouped annuities into four sets by length of guarantee period: 1-4 years, 5 years, 10 years, and, only in the voluntary market, 15 years. We also grouped annuities by degree of escalation: $3 \%$ per annum, $5 \%$ per annum, and $8-8.5 \%$ per annum. In the compulsory market, we found that although guaranteed annuitants as a group are not significantly shorter lived than non-guaranteed annuitants, annuitants with 10 year guarantee periods, the longest in the compulsory market, are significantly shorter lived than annuitants with nonguaranteed annuities. We also found that the hazard increases monotonically with the length of the guarantee period and decreases monotonically with the degree of escalation. The differences between the hazards for 5 and 10 year guaranteed annuities, and for 3\% and 5\% escalating annuities, was significant at conventional confidence levels.

The findings in Table 3 suggest that, in both the voluntary and the compulsory market, longerlived individuals select escalating annuities while shorter-lived individuals select guaranteed annuities. This choice is apparently based on private information about mortality prospects. In addition, in the compulsory annuity market individuals appear to base their choice of the degree of guarantee period or degree of escalation on private mortality information. We do not find evidence of this finer selection in the voluntary market.

Table 3 also provides some evidence that in the compulsory market, annuitants with a higher initial annual payment are longer lived than annuitants with a lower initial annual payment. This is the relationship predicted by the standard models of insurance market equilibrium with adverse selection, provided insurance companies use the amount of the initial payment as a screening variable. In the 
voluntary market, however, we find a positive coefficient on the initial payment variable. This is not consistent with stylized models of self-selection behavior. Our estimates are broadly consistent with market-wide data on the relationship between the size of the annuity and the mortality of the annuitant. For example, the Institute of Actuaries (1999a, 1999b) reports that while those who buy larger compulsory annuity policies tend to live longer than those who buy smaller policies, there is no discernable relationship between annuity size and mortality in the voluntary market.

It is important to note that in both the voluntary and the compulsory market, the estimated effect of the amount of initial payment is small compared to the magnitude of the other screening devices. To illustrate this, we translate the hazard model coefficients into survival probabilities for individuals with different types of annuities. Table 4 presents information on the probability that a 58 -year-old annuity buyer will survive until age 75 , conditional on different types of annuity purchases. The "baseline" survival probability, which is shown in the first row, is that for a 58 year old female annuitant who purchases a nominal, non-guaranteed, annual payment, single life annuity in 1981. This annuity is assumed to pay the company's average initial annuity payment, with different averages used in the voluntary and compulsory markets. Subsequent rows show the corresponding survival probabilities that emerge when we change single dimensions of the annuity policy.

The first column of Table 4 shows the results for the compulsory market. The second column of Table 4 shows the results for the voluntary market. Looking across these columns, our estimates indicate substantially lighter mortality in the voluntary market relative to the compulsory market. This is consistent with market-wide mortality tables for the compulsory and voluntary annuity markets (Institute of Actuaries, 1999a and 199b).

The rows in Table 4 suggest large mortality differences among certain classes of annuitants. For example, in the compulsory market, the baseline annuitant has a $64 \%$ chance of surviving to age 75 . The switch to an index-linked but otherwise-identical annuity is associated with a survival probability of $83 \%$, or a $30 \%$ increase in the survival probability compared to the baseline (nominal) annuity. In contrast, a 
one standard deviation increase in the initial annual annuity payment, from the mean, is only associated with a conditional survival probability of $66 \%$, or a $3 \%$ increase in the $64 \%$ baseline survival probability.

In the voluntary market, we note that the mortality difference associated with guaranteed payments is somewhat smaller than that associated with backloading. For example, the probability that the baseline annuitant survives to 75 is $92 \%$ in the voluntary market. It is $97 \%$ for those in the indexlinked annuity market and $98 \%$ for those in the escalating annuity market, but only $90 \%$ for those in the guaranteed annuity market. These results suggest that annuitants self-select to a greater degree based on the amount of backloading of payments than on the presence or absence of a payout guarantee.

To facilitate interpretation of these mortality differences, we can compare the mortality differences in Table 4 to the mortality differences between male and female annuitants. The mortality table for compulsory annuitants suggests that a 58 -year-old male annuitant has a $42 \%$ chance of surviving until 75. A 58-year-old female annuitant, otherwise identical, has a 64\% chance. A 58-year-old female annuitant who purchases an escalating annuity has an $86 \%$ survival probability to age 75 . Therefore the increase in survival probability associated with purchasing an escalating annuity (34\%) in the compulsory market is about the same as the increase associated with switching the gender of the annuitant from male to female. In the voluntary annuity market, the increase in survival probability associated with purchasing an escalating annuity (7\%) is even larger than the increase associated with being female $(2 \%)$.

The results in Tables 3 and 4 suggest substantial mortality selection based on the backloading of the annuity, some mortality selection based on payments to the estate, and very little - if any - screening of annuitants based on the initial annual payment of the annuity. The lack of selection on initial annual annuity payment supports results obtained by Cawley and Philipson (1999) for life insurance and by Chiappori and Salonie (2000) for auto insurance. These papers examine only one potential screening device. In one study it is the amount paid in the event of death, and in the other it is whether the individual has more than the legally-required minimum level of insurance. Both of these screening variables resemble the initial annual annuity payment in our screening model. While our results, like 
those in the other studies, suggest little screening on this variable, they suggest substantial screening on other margins of insurance policy choice.

There is good reason why insurance companies would not find it effective to screen annuity buyers on the amount of their initial annual payout. Recall that a screening device must be priced to reflect self-selection. Offering marginal prices that increase with the amount of the insurance payment in the event of an accident requires that insurers be able to monitor and to verify the total amount of insurance that each buyer has purchased. This can be difficult, since firms typically know only the amount of insurance that the buyer has purchased from their firm. If firms do not monitor total insurance purchases, then if the marginal price rises with the payment in the event of an accident, individuals who desire a large payment will be better off buying several small policies from different insurance companies rather than one large policy from a single firm.

Monitoring total insurance purchases may be particularly difficult in annuity markets. Unlike life insurance and auto insurance, which pay out only infrequently, if ever, annuities are almost certain to make some payments and may make many payments. For most other insurance products, the insurance company can stipulate that the contract is valid only if the insured has not purchased other insurance, and investigate compliance upon submission of a claim. Doing this with an annuity would require continuous monitoring, and could therefore be quite costly. This has led Abel ((1986) and Brugiavini (1993) to argue that it would be difficult to offer annuities with marginal prices that rose as a function of the annuity payment. $^{3}$

Insurance companies do not face such problems in charging more for backloaded annuities, to reflect the higher average risk pool, or making the price of annuities with payments to the estate lower to reflect lower average risk (higher mortality). Individuals who desire a backloaded annuity cannot replicate such an annuity buy buying several (cheaper) immediate nominal annuities, and someone who wants a guaranteed annuity cannot create such annuity by purchasing multiple non-guaranteed policies. 


\subsection{Sensitivity Analysis}

While our initial findings provide substantial support for the role of selection effects in the annuity market, we also developed several tests designed to explore these results - and their robustness in greater detail. We examined whether the magnitude of selection effects among annuity products varied across groups of annuitants. For example, we tested whether mortality differences across annuity products were of the same magnitude for men and for women. We included a full set of interactions between all of the covariates and the gender of the annuitant in our basic hazard model, while constraining men and women to exhibit the same baseline hazard. We were unable to reject the null hypothesis that selection effects among annuity products were the same for men and for women.

We also subjected the results to a variety of robustness checks. We estimated the hazard models separately for men and women to allow the baseline hazard to be different for these two groups. We estimated the hazard models on several-year subsamples of our complete data set to check whether our results were contaminated by time trends in the annuity market that could be correlated with product characteristics and mortality. And we re-estimated the hazard model using as our duration measure total age rather than years since purchase of the annuity. Virtually all of the results discussed above were robust in sign and significance to these various checks. One notable finding, however, concerns the variable measuring the initial annuity payment. When we estimated separate hazard models for male and female annuitants, this variable was only statistically significant for men in the compulsory market and for women in the voluntary market, with the signs shown in Table 3 . The gender-related difference in this coefficient bears further investigation.

\subsection{Allowing for Unobserved Heterogeneity}

In addition to the robustness checks described above, we also explored the effect of allowing for unobserved heterogeneity of the form described above. Table 5 presents our coefficient estimates for the covariates in the hazard function models, while Table 6 presents the coefficients that describe the baseline

${ }^{3}$ Chiappori (2000) specifically mentions annuities and life insurance as insurance markets where the non-exclusivity of the contract makes a rising marginal price impossible. Cawley and Philipson (1999) find no evidence of a rising 
hazard function. The first and third columns of Table 5 reproduce the results in Table 3, while the second and fourth columns show estimates that allow for unobserved heterogeneity in the compulsory and voluntary market respectively. In both markets, the sign and significance of almost all of our substantive results are robust to allowing for unobserved heterogeneity. The one change of note is that when we allow for unobserved heterogeneity, the coefficient on the indicator variable for capital-protected annuities in the voluntary market becomes statistically significantly different from zero.

The parameter $\sigma^{2}$ is the estimate of the variance of the gamma distribution. Values of this parameter that are statistically significantly different from zero suggest the presence of unobserved heterogeneity. Our findings support the presence of unobserved heterogeneity in the voluntary market but not in the compulsory market. This may indicate that, because of fixed costs associated with offering each product class or other factors, insurance companies do not find it optimal in the voluntary annuity market to screen individuals into perfectly homogeneous product-risk categories. In the substantially larger compulsory market, our results are consistent with the view that individual annuitants have been screened based on their characteristics, and the characteristics of the policies that they buy, into homogeneous risk classes.

Allowing for unobserved heterogeneity affects our estimates of the selection effects in the voluntary market. Simply comparing the coefficients in columns (3) and (4) of Table 5 can be misleading, however, because these coefficients represent proportional shifts in the baseline hazard, and the estimated baseline hazard changes when we allow for unobserved heterogeneity, as can be seen in Table 6. To calibrate the difference in the estimated selection effects in the voluntary market with and without accounting for unobserved heterogeneity, Table 7 reports further calculations of how different covariates affect the probability of the baseline, 58 year old, female annuitant surviving until age 75 . The first column of Table 7 replicates the results in the second column of Table 4 for the voluntary annuity market, modeled under the assumption that there is no unobserved heterogeneity. The second column

marginal price in the life insurance market. 
reports similar estimates for the voluntary market based on the model that allows for unobserved heterogeneity.

Table 7 shows that accounting for unobserved heterogeneity increases our estimates of the selection effects in the voluntary market. For example, without accounting for unobserved heterogeneity, we estimate that buying an index-linked annuity is associated with a 5 percent increase, from $92 \%$ to $97 \%$, in the probability that an annuitant survives until age 75 . Once unobserved heterogeneity is accounted for, purchasing an index-linked annuity is associated with an increase in survival probability from a baseline of $91 \%$ to $98 \%$, an 8 percent increase. Similarly, the reduction in the baseline survival probability associated with a guaranteed annuity is 2 percent when we do not account for unobserved heterogeneity, and 5 percent when we do. Both with and without unobserved heterogeneity, the mortality differences associated with backloading are larger than those associated with gender. The mortality differentials associated with payments to the estate are of the same or smaller size than those associated with gender. These findings underscore the importance of allowing for unobserved heterogeneity, and they suggest that studies of market equilibrium in insurance markets need to recognize the potential presence of such heterogeneity.

\section{Pricing Differences Across Annuity Products}

Our hazard model results suggest clear relationships between annuity product characteristics and annuitant mortality. We now consider the relationship between annuity product characteristics and annuity prices. Recall that if annuitants self-select among insurance products on the basis of private information about their mortality, then in equilibrium, prices on different annuity features should adjust to reflect feature-specific average mortality.

\subsection{Calculating Annuity Prices and the "Money's Worth" Concept}

The price of an annuity is not the premium that the annuitant pays when he or she purchases an annuity, but the differential between this premium and the expected present discounted value of annuity payouts. The price is therefore related to the annuity's "money's worth," which earlier studies such as 
Mitchell, et al. (1999) have defined as the expected discounted present value of annuity payouts divided by the premium. The expected present discounted value is calculated using the mortality curve of a typical individual in the population, so an annuity that is actuarially fair for such an individual will have a money's worth of unity. Money's worth values may be less than one when there are administrative costs associated with the annuity policy, or if the mortality rate of the individuals buying an annuity is lower than that in the population at large. One minus the money's worth value equals the price of the annuity.

If the individuals who buy annuity product $\mathrm{j}$ are, on average, longer-lived than individuals who buy annuity product $\mathrm{k}$, then insurance companies will reflect these mortality differences in their pricing. Assuming that an insurance company's costs and markup are the same across products, a given premium should therefore purchase a lower payment stream for product $\mathrm{j}$ than for product $\mathrm{k}$ since the buyers of product $\mathrm{j}$ will, on average, outlive the buyers of product $\mathrm{k}$. From the standpoint of an individual facing a given mortality table, such as the population mortality table, product $\mathrm{j}$ should have a lower expected present discounted value of payments, and hence a lower money's worth, than product $\mathrm{k}$. This implies that annuity product $\mathrm{j}$ should have a higher price than annuity product $\mathrm{k}$.

The formula for the money's worth of a nominal, non-guaranteed annuity is:

$$
\mathrm{MW}_{\text {NOM }}=\frac{\sum_{\mathrm{t}=1}^{\mathrm{T}} \frac{\mathrm{A} * \mathrm{~S}_{\mathrm{t}}}{\prod_{\mathrm{j}=1}^{\mathrm{t}}\left(1+\mathrm{i}_{\mathrm{j}}\right)}}{\mathrm{P}}
$$

In this expression, A denotes the per-period payment from the nominal annuity, $\mathrm{P}$ denotes the initial premium payment, $\mathrm{S}_{\mathrm{t}}$ denotes the probability that the annuitant survives until payment period $\mathrm{t}$, and $\mathrm{i}_{\mathrm{j}}$ denotes the expected nominal interest rate at time period $\mathrm{j}$. The above formula is easily adjusted, as in Finkelstein and Poterba (1999), for the case of index-linked or escalating annuities, and for annuities that make payments to the annuitant's estate.

We calculate the money's worth value for each annuity in our data set using a common mortality table, the U.K. population cohort mortality table provided by the Government Actuaries' Department. This mortality table provides current and projected future mortality rates by age and sex, and we use the 
relevant rates for each individual who buys an annuity in our data set. In each case, we use mortality tables from the year in which the annuity is sold. For example, for a 65-year-old male who purchased an annuity in 1988, we use the 1988 population projections of his survival probability in each successive year. We use the zero-coupon yield curve of nominal U.K. Treasury securities on the day of annuity purchase to measure the term structure of nominal interest rates in equation (8). In calculating the money's worth of inflation-indexed annuities, we use data on the expected rate of inflation, as reported by the Bank of England, on the day of annuity purchase.

To explore how annuity prices are related to product characteristics, we regress the price of the annuity, defined as one minus the money's worth of the annuity, on characteristics of the annuity and the annuitant. The hedonic pricing equation, which we estimate by ordinary least squares, is:

$$
\begin{aligned}
& \text { PRICE }_{\mathrm{i}}=\alpha+\beta_{1} \text { INDEX }_{\mathrm{i}}+\beta_{2} \text { ESCALATING }_{\mathrm{i}}+\beta_{3} \text { GUARANTEED }_{\mathrm{i}}+\beta_{4} \text { CAPITAL }_{\mathrm{i}} \\
& +\beta_{5} \text { PAYMENT }_{\mathrm{i}}+\beta_{6} \text { PAYMENT }^{2}{ }_{i}+\beta_{7} \mathrm{X}_{\mathrm{i}}+\varepsilon_{\mathrm{i}}
\end{aligned}
$$

$\mathrm{X}$ consists of all known features of the annuitant and the annuity product that are not labeled separately. These include the age of the annuitant at time of purchase (in five year groupings), the gender of the annuitant, the year of purchase, and a series of indicator variables for the frequency of the annuity payments. All of these variables were used in our hazard model analysis above.

Equilibrium requires that the prices of various annuity product features are affected by the selection behavior of different mortality types. We therefore expect a positive coefficient on an indicator variable for whether the annuity is index-linked and on an indicator for whether the annuity is escalating. Because we found the mortality of the annuitants who buy these products to be lower than that of nominal annuitants, we expect that the annual payments offered on these products will be lower than those for nominal annuities. This reflects the fact that escalating and indexed annuitants are likely to live longer than the annuitants who buy plain nominal annuities. As a result of the lower annual payments, the money's worth calculated using a common mortality table will be lower, and the price of the annuity will be higher, for escalating or indexed products than for nominal ones. Similarly, we expect a negative 
coefficient on indicator variables for whether the annuity is guaranteed and whether it is capital protected. Table 1 summarizes these predictions in columns three and four.

The existence of pricing differentials such as those described in the previous paragraph are critical to the screening equilibrium described above. If insurance features that are purchased by higher risk individuals are not priced higher than those purchased by lower-risk individuals, then the incentive compatibility constraint of the low risk type would be violated. Since low risk individuals get less than their desired insurance, they would want to switch to the full-insurance, high-risk package if prices did not vary across packages.

\subsection{Empirical Findings}

Table 8 reports the hedonic regression results, which are generally supportive of the pricing patterns predicted by the screening equilibrium model. The estimated coefficients on the indicator variables for guaranteed and capital protected annuities indicate that annuities that make payments to the estate have significantly lower prices in both the compulsory and voluntary market than do annuities that do not make payments to the estate. This is consistent with the foregoing hazard model results that suggest that annuitants who purchase annuities that make payments to the estate are shorter lived (lower risk) than annuitants who purchase annuities that do not make payments to the estate. The results for backloading are similarly supportive. Index-linked annuities are priced significantly higher than nominal annuities in both the compulsory and voluntary market, reflecting the fact that the typical annuitant who purchases an index-linked annuity is longer lived (higher risk) than the typical annuitant who purchases a nominal annuity. In the compulsory market, but not the voluntary market, there is also evidence that, as predicted, escalating annuities have higher prices than nominal annuities.

In results not reported here, we also examined the relative prices of annuities with different degrees of escalation and different guarantee periods. In the compulsory market, consistent with the selection results reported above, the annuity price rises monotonically in the amount of escalation and falls monotonically with the length of guarantee period. The pricing differences among annuities of different guarantee lengths are statistically significantly different from zero, while those among annuities 
with different escalation rates are not. There is no clear pricing pattern for different degrees of escalation in the voluntary market, but the annuity price does fall monotonically with the length of guarantee period. The price difference between a five- and ten-year guaranteed annuity is statistically significantly different from zero, although the price differences between other guarantees are not.

The hedonic pricing equations also include the amount of the initial annuity payment. The negative coefficients on this variable in both markets are indicative of bulk discounts similar to those found by Cawley and Philipson (1999) in the U.S. life insurance market. The positive coefficient on the square of the initial annual payment is consistent with Rothschild and Stiglitz' (1976) prediction of a higher marginal price for larger quantities of insurance. However the magnitude of the coefficient is tiny, which suggests relatively little mortality screening or pricing response to this variable.

Chiappori and Salanie (2000) and Chiappori (2000) note that estimation of a firm's pricing policy is notoriously difficult. Fixed costs and economies of scale and scope can introduce non-linearities in a firm's pricing schedule. Such nonlinearities can be difficult to distinguish from the predictions of models of asymmetric information. Fortunately, we have direct information on the sample firm's firm's pricing policies in addition to the hedonic pricing relationship estimated above. We were told that for the insurance firm that we are studying, the pricing formula is as follows. Within a given class (guarantee period, tilt, frequency of payment, gender and age), if a $£ 10,000$ purchase price buys an annual payment of $\mathrm{A}$, then a purchase price of $\mathrm{P}$ buys an annual annuity payment of $\left.\left(\mathrm{P}^{*} \mathrm{~A}\right) / 10,000+\left([\mathrm{P}-10,000]^{*} \mathrm{f}\right) / 10,000\right)$ where $\mathrm{f}$ is the fixed policy fee. This formula applies both in the voluntary and the compulsory market.

To illustrate this pricing formula, consider an example. With $£ 10,000$ in 1999 , a 65 -year-old man could purchase an index-linked, single life, monthly payment, non-guaranteed annuity with an annual payment of $£ 539.64$. The fixed policy fee (f) was $£ 18$. This formula indicates the presence of bulk discounts for policies of less than $£ 10,000$ and it indicates a constant marginal price. Our estimates suggesting a very small bulk discount and an even smaller rising marginal price of increased annual payments are consistent with the pricing policy. More importantly, this linear pricing scheme is 
consistent with our findings that the insurance company does not use the initial annual payment to screen individuals into risk categories.

\section{Conclusion and Discussion}

This paper uses a unique data set of the annuitants at a large U.K. insurance company to provide new evidence of the presence of asymmetric information in insurance markets. Our results are consistent with the view that individuals self-select across annuity products based on private information about their mortality. We also find that, as would be expected in equilibrium, the pricing of different annuity products reflects the product-specific average mortality of annuity buyers. This evidence is robust to alternative specifications of the model and to various changes in the sample on which we estimate hazard models for mortality. It is also robust to the extending our basic hazard model to allow for unobserved heterogeneity across individuals.

We find the clearest evidence of self-selection on two attributes of annuity policies that are potential screening devices: the time profile (backloading) of the annuity, and whether it promises any payments to the estate of the annuitant. All else equal, annuitants who are longer lived select annuities with payment streams that are backloaded and that therefore pay out relatively more of their value in later years. Similarly, annuitants who are shorter lived select annuities that make payments to the annuitant's estate in the event of an early death. These selection effects are large. For example, in the compulsory annuity market, the mortality difference between otherwise identical individuals who purchase backloaded and non-backloaded annuities is similar in magnitude to the mortality difference between men and women. In the voluntary market, the mortality difference between backloaded and non-backloaded annuitants is several times larger than that between men and women. We also find evidence that relatively backloaded annuities are priced higher than less backloaded annuities. Annuities with payments to the estate are priced lower than annuities that do not make payments to the estate, which is what we expect if insurance companies take account of selection effects in setting their prices. 
Our results broadly confirm the prediction of models of asymmetric information in insurance markets that emphasize a positive correlation between risk type and characteristics of the insurance policy that are of greater value to high risk individuals. Our findings on the differential mortality experience of annuitants who purchase different types of policies are consistent with individual having private information about their mortality experience, and acting on this information in their insurance purchases. These findings are complementary to survey-based studies, such as Hamermesh (1985) and Hurd and McGarry (1997) that have explored the extent to which individuals have informed, and plausible, views about their potential life expectancy. Such studies present evidence that individuals have private mortality information. Our results are not only consistent with individuals having private mortality information but also suggest that they use this information in making financial decisions about their later years.

While our results are consistent with the presence of adverse selection in the annuity market, two other potential explanations of our findings that warrant some discussion. The first is the possibility that our results are an artifact of the particular firm whose annuity sales we have analyzed. This small sample concern is difficult to address without detailed data from other insurance firms, and we do not have such data. However, our comparison of characteristics of the sample of annuities sold by the insurance company whose policies we study with characteristics of the aggregate U.K. market did not suggest obvious differences in the pool of policyholders. Furthermore, although we only have detailed pricing and mortality data from one insurance company, Finkelstein and Poterba (1999) report on the pricing of annuities with different guarantee periods and different degrees of backloading in a sample of the major U.K. annuity companies. The aggregate patterns match those found for the single firm considered in here.

A second concern is that our findings are not the result of adverse selection, but rather moral hazard. If individuals who purchase more insurance change their behavior in a way that results in higher claims against their insurance company, then we would observe the patterns we have documented in the relative mortality of different groups of annuitants. It is notoriously difficult to distinguish empirically between adverse selection and moral hazard. Even without such a distinction, our results provide evidence that is strongly suggestive of some type of asymmetric information in the annuity market. Our findings 
therefore stand in contrast to the recent claims of symmetric information in insurance markets, such as those by Cawley and Philipson (1999) and Chiappori and Salanie (2000). Moreover, the case for interpreting findings like ours as due to moral hazard is arguably weaker for annuity markets than for most other insurance markets.

For the moral hazard analysis to apply to annuities, the conversion of income to an annuity stream must affect the individual's mortality. It is difficult to think of a convincing mechanism for this. For example, since individuals with an insured income stream can consume more each period because they do not have to save for the possibility of outliving their resources, it could be argued that this increased consumption possibilities frontier improves their mortality. Philipson and Becker (1998) note that in principle the presence of annuity income may have effects on individual efforts to extend length of life, although they suspect that such effects are more likely to be important in developing than in currently developed nations. Even recognizing this potential effect, the importance of moral hazard in annuity markets is likely to be much smaller than that in many other insurance markets. Banks and Emmerson (1999) report that among both voluntary and compulsory annuitants in the U.K., annuity income represents less than one fifth of annual income. This reduces the likelihood that the form of the income stream is affecting mortality.

One of our most important results is that we do not find evidence of self-selection on the initial amount of annuity payment. This initial amount of annuity payment is analogous to measures of the accident-induced payment that are used in other empirical papers on asymmetric information in insurance markets. We find no evidence of a positive correlation between risk type and payment in the event of an accident in annuity markets. This is consistent with the evidence found in other insurance markets such as those studied by Cawley and Philipson (1999) and Chiappori and Salanie (2000). Consistent with the lack of selection on initial annuity payments, we find that the price of additional increments of initial annuity payment is linear. Cawley and Philipson (1999) report similar findings for the life insurance market. We do, however, find evidence of self-selection and pricing responses on other features of the annuity insurance contract. Our research therefore highlights the importance of paying careful attention to 
the detailed policy features of real-world insurance contracts when testing theoretical models of asymmetric information in insurance markets. 


\section{BIBLIOGRAPHY}

Abel, Andrew B. 1986. Capital Accumulation and Uncertain Lifetimes with Adverse Selection. Econometrica 54 (September), pp.1079-1097.

Association of British Insurers. 1997. Insurance Statistics Year Book: 1986-1996. London: ABI.

Banks, James and Carl Emmerson. 1999. UK Annuitants. London: Institute for Fiscal Studies. http://www.ifs.org.uk/publications/briefnotes.shtml

Brown, Jeffrey, Olivia Mitchell, and James Poterba. 2000. Mortality Risk, Inflation Risk, and Annuity Products. NBER Working Paper 7812.

Brown, Jeffrey and James Poterba. 2000. Joint Life Annuities and Annuity Demand by Married Couples. Journal of Risk and Insurance (forthcoming).

Brugiavini, A. 1993. Uncertainty Resolution and the Timing of Annuity Purchases. Journal of Public Economics, 50, pp.31-62.

Cawley, John and Tomas Philipson. 1999. An Empirical Examination of Information Barriers to Trade in Insurance. American Economic Review 89(4), pp.827-846.

Chiappori, Pierre-Andre. 2000. Econometric Models of Insurance under Asymmetric Information. In Georges Dionne, ed. Handbook of Insurance Economics. London: Kluwer (forthcoming).

Chiappori, Pierre-Andre and Bernard Salanie. 2000. Testing for Asymmetric Information in Insurance Markets. Journal of Political Economy, 108, 56-78.

Cordon, James and Igal Hendel. 1999. Asymmetric Information in Health Insurance: Evidence from the National Medical Expenditure Survey. Unpublished Mimeo, Princeton University Department of Economics..

Finkelstein, Amy and James Poterba. 1999. Selection Effects in the Market for Individual Annuities: New Evidence from the United Kingdom. NBER Working Paper 7168.

Friedman, Benjamin, and Mark Warshawsky. 1988. Annuity prices and saving behavior in the United States. In Z. Bodie, J. Shoven, and D. Wise, eds. Pensions in the US Economy. Chicago: University of Chicago Press.

Friedman, Benjamin, and Mark Warshawsky. 1990. The cost of annuities: Implications for saving behavior and bequests. Quarterly Journal of Economics 105 (February), pp.135-154.

Hamermesh, Daniel. 1985. Expectations, Life Expectancy, and Economic Behavior. Quarterly Journal of Economics 100(May), 389-408.

Han, Aaron and Jerry Hausman. 1990. Flexible Parametric Estimation of Duration and Competing Risk Models. Journal of Applied Econometrics. 5:1-28.

Hurd, Michael and Kathleen McGarry. 1997. The Predictive Validity of Subjective Probabilities of Survival. NBER Working Paper 6193. 
Institute of Actuaries and Faculty of Actuaries, Continuous Mortality Investigation Committee. 1999a. Continuous Mortality Investigation Reports, Number 16.

Institute of Actuaries and Faculty of Actuaries, Continuous Mortality Investigation Committee. 1999b. Continuous Mortality Investigation Reports, Number 17.

Meyer, Bruce. 1990. Unemployment Insurance and Unemployment Spells. Econometrica, 58(4): 757-782.

Mitchell, Olivia S., James M. Poterba, Mark Warshawsky, and Jeffrey R. Brown. 1999. New Evidence on the money's worth of individual annuities. American Economic Review, 89(December), pp.12991318.

Murthi, Mamta, J. Michael Orszag, and Peter Orszag. 1999. The Charge Ratio on Individual Accounts: Lessons for the U.K. Experience. Birkbeck College, University of London Working Paper 99-2.

Philipson, Tomas and Gary Becker. 1998. Old-Age Longevity and Mortality-Contingent Claims. Journal of Political Economy, 106: 551-573.

Poterba, James and Mark Warshawsky. 2000. The Costs of Annuitizing Retirement Payments from Individual Accounts. In John Shoven, ed. Administrative Costs and Social Security Privatization. Chicago: University of Chicago Press, 173-200.

Pueltz, Robert and Arthur Snow. 1994. Evidence on Adverse Selection: Equilibrium Signaling and CrossSubsidization in the Insurance Market. Journal of Political Economy, 102: 236-257.

Rothschild, Michael and Joseph Stiglitz. 1976. An Essay on the Economics of Imperfect Information. Quarterly Journal of Economics 90 (November), pp.629-649.

Smart, Michael. 2000. Competitive Insurance Markets with Two Unobservables. International Economic Review 41 (February), 153-169.

Yaari, Menahem. 1965. Uncertain Lifetimes, Life Insurance, and the Theory of the Consumer. Review of Economic Studies 32: 137-150. 
TABLE 1:

PREDICTIONS OF ASYMMETRIC INFORMATION MODELS FOR ANNUITY MARKETS

\begin{tabular}{|c|c|c|c|c|}
\hline \multirow{6}{*}{$\begin{array}{l}\text { ANNUITY } \\
\text { FEATURE / } \\
\text { POTENTIAL } \\
\text { SCREENING } \\
\text { DEVICE }\end{array}$} & \multicolumn{2}{|c|}{ "MORTALITY PATTERN } & \multicolumn{2}{|c|}{ PRICING RESPONSE } \\
\hline & (1) & & (3) & \\
\hline & Mortality & Coefficient & Pricing Difference & Coefficient in \\
\hline & Difference & in Hazard & & Hedonic \\
\hline & & Model & & Price \\
\hline & & & & Equation \\
\hline $\begin{array}{l}\text { BACKLOADED } \\
\text { ANNUITIES }\end{array}$ & $\begin{array}{l}\text { Backloaded annuity } \\
\text { buyers will be } \\
\text { longer lived than } \\
\text { nominal annuity } \\
\text { buyers }\end{array}$ & Negative & $\begin{array}{l}\text { Backloaded } \\
\text { annuities will have } \\
\text { higher relative prices }\end{array}$ & Positive \\
\hline $\begin{array}{l}\text { PAYMENTS TO } \\
\text { THE ESTATE }\end{array}$ & $\begin{array}{l}\text { Annuitants with } \\
\text { annuities that make } \\
\text { payments to the } \\
\text { estate will be } \\
\text { shorter lived }\end{array}$ & Positive & $\begin{array}{l}\text { Annuities with } \\
\text { guarantees will have } \\
\text { lower relative prices }\end{array}$ & Negative \\
\hline $\begin{array}{l}\text { INITIAL } \\
\text { ANNUAL } \\
\text { ANNUITY } \\
\text { PAYMENT }\end{array}$ & $\begin{array}{l}\text { Annuitants with } \\
\text { larger initial annual } \\
\text { payments will be } \\
\text { longer lived }\end{array}$ & Negative & $\begin{array}{l}\text { Rising Marginal } \\
\text { Price }\end{array}$ & $\begin{array}{l}\text { Positive } \\
\text { coefficient on } \\
\text { square of } \\
\text { variable }\end{array}$ \\
\hline
\end{tabular}


TABLE 2: OVERVIEW OF THE COMPULSORY AND VOLUNTARY MARKET

\begin{tabular}{|c|c|c|}
\hline & $\begin{array}{r}\text { COMPULSORY } \\
\text { MARKET } \\
\end{array}$ & $\begin{array}{r}\text { VOLUNTARY } \\
\text { MARKET } \\
\end{array}$ \\
\hline Number of policies & 38,362 & 3,692 \\
\hline $\begin{array}{l}\text { Number }(\%) \text { of annuitants } \\
\text { who are deceased. }\end{array}$ & $\begin{array}{r}6,311 \\
(16.5 \%)\end{array}$ & $\begin{array}{r}1,944 \\
(52.7 \%)\end{array}$ \\
\hline $\begin{array}{l}\text { Number }(\%) \text { of annuitants } \\
\text { who are male }\end{array}$ & $\begin{array}{r}29,681 \\
(77.4 \%)\end{array}$ & $\begin{array}{r}1,272 \\
(34.5)\end{array}$ \\
\hline \multirow[t]{2}{*}{ Average age at purchase } & 63.2 & 76.4 \\
\hline & \multicolumn{2}{|c|}{ Backloaded Annuities } \\
\hline $\begin{array}{l}\text { Number }(\%) \text { of policies that } \\
\text { are index-linked }\end{array}$ & $\begin{array}{r}428 \\
(1.3 \%)\end{array}$ & $\begin{array}{r}66 \\
(3.5 \%)\end{array}$ \\
\hline \multirow[t]{2}{*}{$\begin{array}{l}\text { Number }(\%) \text { of policies that } \\
\text { are escalating in nominal } \\
\text { terms }\end{array}$} & $\begin{array}{r}1,492 \\
(3.9 \%)\end{array}$ & $\begin{array}{r}175 \\
(4.7 \%)\end{array}$ \\
\hline & \multicolumn{2}{|c|}{ Payments to Estate } \\
\hline $\begin{array}{l}\text { Number }(\%) \text { of policies that } \\
\text { are guaranteed }\end{array}$ & $\begin{array}{r}28,424 \\
(74.1 \%)\end{array}$ & $\begin{array}{r}872 \\
(23.6 \%)\end{array}$ \\
\hline \multirow[t]{2}{*}{$\begin{array}{l}\text { Number }(\%) \text { of policies that } \\
\text { are capital protected }\end{array}$} & 0 & $843(22.8 \%)$ \\
\hline & \multicolumn{2}{|c|}{ Initial Annual Annuity Payments } \\
\hline Average Initial Payment (£) & 1,151 & 4,773 \\
\hline Median Initial Payment (£) & 627 & 3,136 \\
\hline $\begin{array}{l}\text { Standard Deviation of Initial } \\
\text { Payment }(£)\end{array}$ & 1,929 & 5,229 \\
\hline
\end{tabular}

Average Premium (£)

10,523

25,603

Notes: All monetary figures in the paper are in December 1998 pounds. The first index-linked policy was sold in February 1985; therefore percentage of policies index-linked refers to percentage of policies sold since that date. 
TABLE 3: SELECTION EFFECTS AND ANNUITY PRODUCT CHARACTERISTICS

COMPULSORY MARKET VOLUNTARY MARKET

\section{Backloaded Annuities}

INDEX-LINKED

$-0.839 * * *$

$-0.894 * *$

ESCALATING

$-1.085^{* * *}$

$(0.113)$

$-1.497 * * *$

$(0.253)$

\section{Payments to Estate}

GUARANTEED

0.019

(0.029)

$0.216^{* * *}$

(0.060)

CAPITAL-PROTECTED

0.056

$(0.051)$

\section{Initial Annuity Payment}

\section{PAYMENT (in $£ 100$ s)}

$\begin{array}{rr}-0.003 * * * & 0.001 * * \\ (0.0006) & (0.0004)\end{array}$

\begin{tabular}{lrr}
\hline $\mathrm{N}$ & 38,362 & 3,692 \\
Number of deaths in sample & 6,311 & 1,944 \\
\hline \hline
\end{tabular}

Note: All estimates are from Han-Hausman discrete-time, semi-parametric proportional hazard models. These are estimated using 17 annual discrete time intervals. Baseline hazard parameters are not reported. Indicator variables for five-year intervals for age at purchase, and for year of purchase, are included in all regressions, along with indicator variables for gender and for the frequency of payments. Standard errors are in parentheses. The omitted category for the "tilt" dummies (index-linked and escalating) is nominal annuities. The omitted category for the guarantee feature dummies (guaranteed and capital protected) is not guaranteed and not capital protected. *, **, and *** denote statistical significance at the $10 \%, 5 \%$, and $1 \%$ levels, respectively. 
TABLE 4: INTERPRETING SELECTION EFFECTS: PROBABILITY OF SURVIVING UNTIL AGE 75 FOR DIFFERENT TYPES OF ANNUITY BUYERS

\begin{tabular}{lcc}
\hline \hline & COMPULSORY MARKET & \multicolumn{2}{c}{ VOLUNTARY MARKET } \\
\hline Baseline & 0.641 & 0.916 \\
Index-linked annuity & 0.827 & 0.965 \\
Escalating Annuity & 0.862 & 0.981 \\
Guaranteed Annuity & 0.635 & 0.897 \\
Capital Protected Annuity & - & 0.912 \\
Initial Annual Annuity & & 0.912 \\
Payment One Standard & 0.657 & \\
Deviation Above the Mean & & 0.893 \\
Male Annuitant & 0.423 &
\end{tabular}

Note: Baseline survival probability is for a 58 year old female annuitant with a nominal, non-guaranteed, annual payment, single life annuity purchased in 1981 and paying the mean initial annual annuity payment for the compulsory or voluntary market. Other rows reflect the survival probability of an annuitant who has the baseline characteristics and the baseline annuity except for the change noted in the first column. 
TABLE 5:

SELECTION EFFECTS AND ANNUITY PRODUCT CHARACTERISTICS: ESTIMATES WITH AND WITHOUT GAMMA HETEROGENEITY

\begin{tabular}{|c|c|c|c|c|}
\hline & \multicolumn{2}{|c|}{ COMPULSORY MARKET } & \multicolumn{2}{|c|}{ VOLUNTARY MARKET } \\
\hline & $\begin{array}{r}\text { No } \\
\text { Heterogeneity } \\
\text { Factor } \\
(1)\end{array}$ & $\begin{array}{l}\text { Allowing For } \\
\text { Heterogeneity } \\
\text { (2) }\end{array}$ & $\begin{array}{r}\text { No } \\
\text { Heterogeneity } \\
\text { Factor } \\
(3)\end{array}$ & $\begin{array}{r}\text { Allowing For } \\
\text { Heterogeneity } \\
\text { (4) }\end{array}$ \\
\hline IINDEX-LINKED & $\begin{array}{r}-0.839 * * * \\
(0.217)\end{array}$ & $\begin{array}{r}-0.874 * * * \\
(0.222)\end{array}$ & $\begin{array}{r}-0.894^{* *} \\
(0.358)\end{array}$ & $\begin{array}{r}-1.671 * * * \\
(0.582)\end{array}$ \\
\hline ESCALATING & $\begin{array}{r}-1.085^{* * * *} \\
(0.113)\end{array}$ & $\begin{array}{r}-1.114 * * * \\
(0.122)\end{array}$ & $\begin{array}{r}-1.497 * * * \\
(0.253)\end{array}$ & $\begin{array}{r}-2.442 * * * \\
(0.352)\end{array}$ \\
\hline MALE ANNUITANT & $\begin{array}{r}0.640 * * * \\
(0.039)\end{array}$ & $\begin{array}{r}0.663 * * * \\
(0.045)\end{array}$ & $\begin{array}{r}0.252 * * * \\
(0.051)\end{array}$ & $\begin{array}{r}0.463 * * * \\
(0.094)\end{array}$ \\
\hline GUARANTEED & $\begin{array}{r}0.019 \\
(0.029)\end{array}$ & $\begin{array}{r}0.024 \\
(0.031)\end{array}$ & $\begin{array}{r}0.216^{* * * *} \\
(0.060)\end{array}$ & $\begin{array}{r}0.423 * * * \\
(0.105)\end{array}$ \\
\hline CAPITAL PROTECTED & & & $\begin{array}{r}0.056 \\
(0.051)\end{array}$ & $\begin{array}{r}0.389 * * * \\
(.105)\end{array}$ \\
\hline $\begin{array}{l}\text { SEMI-ANNUAL } \\
\text { PAYMENTS }\end{array}$ & $\begin{array}{r}-0.020 \\
(0.048)\end{array}$ & $\begin{array}{r}-0.025 \\
(0.051)\end{array}$ & $\begin{array}{r}0.121 \\
(0.111)\end{array}$ & $\begin{array}{r}0.296 \\
(0.184)\end{array}$ \\
\hline TERMLY PAYMENTS & $\begin{array}{r}-0.424 \\
(0.428)\end{array}$ & $\begin{array}{r}-0.257 \\
(0.436)\end{array}$ & - & \\
\hline $\begin{array}{l}\text { QUARTERLY } \\
\text { PAYMENTS }\end{array}$ & $\begin{array}{r}0.004 \\
(0.038)\end{array}$ & $\begin{array}{r}0.0009 \\
(0.040)\end{array}$ & $\begin{array}{r}0.165 \\
(0.108)\end{array}$ & $\begin{array}{r}0.406^{* *} \\
(0.180)\end{array}$ \\
\hline $\begin{array}{l}\text { MONTHLY } \\
\text { PAYMENTS }\end{array}$ & $\begin{array}{r}-0.006 \\
(0.034)\end{array}$ & $\begin{array}{l}-0.008 \\
(0.036)\end{array}$ & $\begin{array}{r}0.256^{* * *} * \\
(0.099)\end{array}$ & $\begin{array}{r}0.544 * * * \\
(0.162)\end{array}$ \\
\hline PAYMENT (in $£ 100$ s) & $\begin{array}{r}-0.003 * * * \\
(0.0006)\end{array}$ & $\begin{array}{r}-0.003 * * * \\
(0.0006)\end{array}$ & $\begin{array}{l}0.001 * * \\
(0.0004)\end{array}$ & $\begin{array}{r}0.001 \\
(0.0009)\end{array}$ \\
\hline$\sigma^{2}$ & ------------- & $\begin{array}{r}0.253 \\
(0.241) \\
\end{array}$ & ------------ & $\begin{array}{r}2.021 * * * \\
(0.216)\end{array}$ \\
\hline
\end{tabular}

Notes: All estimates are from Han-Hausman discrete-time, semi-parametric proportional hazard models. These are estimated using 17 annual discrete time intervals. Table 6 reports the baseline hazard parameters. Indicator variables for age at purchase (in five-year intervals) and year of purchase are included in all regressions. Standard errors are shown in parentheses. The omitted category for the "tilt" dummies (index-linked and escalating) is nominal annuities, for the guarantee feature dummies (guaranteed and capital protected) is not guaranteed and not capital protected, for the frequency of payment dummies is annual payments. $\sigma^{2}$ is the estimated variance of the gamma heterogeneity. *, **, and $* * *$ indicate statistical significance at the $10 \%, 5 \%$, and $1 \%$ levels, respectively. Sample size for first two (last two) columns is $38,362(3,692)$, with $6,311(1,944)$ annuitant deaths within sample. 
TABLE 6: BASELINE HAZARD FUNCTION WITH AND WITHOUT GAMMA HETEROGENEITY

\begin{tabular}{|c|c|c|c|c|}
\hline \multirow{4}{*}{ Years } & \multicolumn{2}{|c|}{ COMPULSORY MARKET } & \multicolumn{2}{|c|}{ VOLUNTARY MARKET } \\
\hline & No Heterogeneity & Allowing for & No Heterogeneity & Allowing for \\
\hline & Factor & Heterogeneity & Factor & Heterogeneity \\
\hline & (1) & $(2)$ & (3) & $(4)$ \\
\hline \multirow[t]{2}{*}{1} & 0.0091 & 0.0090 & 0.0011 & 0.0001 \\
\hline & $(0.0008)$ & $(0.0008)$ & $(0.0003)$ & $(0.0001)$ \\
\hline \multirow[t]{2}{*}{2} & 0.0104 & 0.0103 & 0.0018 & 0.0002 \\
\hline & $(0.0009)$ & $(0.0009)$ & $(0.0005)$ & $(0.0001)$ \\
\hline \multirow[t]{2}{*}{3} & 0.0110 & 0.0110 & 0.0022 & 0.0003 \\
\hline & $(0.0010)$ & $(0.0010)$ & $(0.0006)$ & $(0.0002)$ \\
\hline \multirow[t]{2}{*}{4} & 0.0144 & 0.0144 & 0.0024 & 0.0004 \\
\hline & $(0.0012)$ & $(0.0013)$ & $(0.0006)$ & $(0.0002)$ \\
\hline \multirow[t]{2}{*}{5} & 0.0146 & 0.0148 & 0.0030 & 0.0007 \\
\hline & $(0.0012)$ & $(0.0013)$ & $(0.0008)$ & $(0.0004)$ \\
\hline \multirow[t]{2}{*}{6} & 0.0166 & 0.0169 & 0.0027 & 0.0008 \\
\hline & $(0.0014)$ & $(0.0015)$ & $(0.0007)$ & $(0.0004)$ \\
\hline \multirow[t]{2}{*}{7} & 0.0182 & 0.0187 & 0.0032 & 0.0011 \\
\hline & $(0.0015)$ & $(0.0016)$ & $(0.0008)$ & $(0.0006)$ \\
\hline \multirow[t]{2}{*}{8} & 0.0195 & 0.0202 & 0.0036 & 0.0015 \\
\hline & $(0.0016)$ & $(0.0018)$ & $(0.0009)$ & $(0.0008)$ \\
\hline \multirow[t]{2}{*}{9} & 0.0213 & 0.0224 & 0.0032 & 0.0016 \\
\hline & $(0.0018)$ & $(0.0021)$ & $(0.0008)$ & $(0.0008)$ \\
\hline \multirow[t]{2}{*}{10} & 0.0224 & 0.0237 & 0.0038 & 0.0022 \\
\hline & $(0.0019)$ & $(0.0023)$ & $(0.0009)$ & $(0.0011)$ \\
\hline \multirow[t]{2}{*}{11} & 0.0256 & 0.0275 & 0.0042 & 0.0030 \\
\hline & $(0.0022)$ & $(0.0028)$ & $(0.0010)$ & $(0.0014)$ \\
\hline \multirow[t]{2}{*}{12} & 0.0305 & 0.0331 & 0.0039 & 0.0032 \\
\hline & $(0.0027)$ & $(0.0037)$ & $(0.0009)$ & $(0.0015)$ \\
\hline \multirow[t]{2}{*}{13} & 0.0334 & 0.0368 & 0.0039 & 0.0037 \\
\hline & $(0.0029)$ & $(0.0044)$ & (0.0009) & $(0.0017)$ \\
\hline \multirow[t]{2}{*}{14} & 0.0345 & 0.0387 & 0.0063 & 0.0068 \\
\hline & $(0.0033)$ & $(0.0051)$ & $(0.0016)$ & $(0.0032)$ \\
\hline \multirow[t]{2}{*}{15} & 0.0391 & 0.0446 & 0.0056 & 0.0069 \\
\hline & $(0.0040)$ & $(0.0069)$ & $(0.0014)$ & $(0.0033)$ \\
\hline \multirow[t]{2}{*}{16} & 0.0519 & 0.0603 & 0.0060 & 0.0086 \\
\hline & $(0.0061)$ & $(0.0105)$ & $(0.0016)$ & $(0.0041)$ \\
\hline \multirow[t]{2}{*}{17} & 0.0800 & 0.0956 & 0.0260 & 0.0452 \\
\hline & $(0.0125)$ & $(0.0215)$ & $(0.0089)$ & $(0.0249)$ \\
\hline
\end{tabular}

Note: The estimates are for the baseline hazard parameters from the Han-Hausman hazard models fit to data on the voluntary and compulsory market. Coefficients for the covariates in these models are shown in Table 5. Standard errors (computed using the delta method) are in parentheses. The baseline hazard represents the hazard of a 55-60 year old female annuitant who purchased a nominal, non-guaranteed, annual payment, single life annuity in 1981. 
TABLE 7:

THE IMPACT OF MODELLING HETEROGENEITY ON THE ESTIMATED PROBABILITY OF VOLUNTARY ANNUITANT SURVIVING UNTIL AGE 75

\begin{tabular}{lcc}
\hline \hline & $\begin{array}{r}\text { NO HETEROGENEITY } \\
\text { FACTOR }\end{array}$ & $\begin{array}{c}\text { ALOWING FOR } \\
\text { HETEROGENEITY }\end{array}$ \\
\hline Baseline & 0.916 & 0.912 \\
Index-linked annuity & 0.965 & 0.983 \\
Escalating Annuity & 0.981 & 0.992 \\
Guaranteed Annuity & 0.897 & 0.868 \\
Capital Protected & 0.912 & 0.908 \\
$\begin{array}{l}\text { Initial annual annuity payment one } \\
\text { standard deviation above the mean }\end{array}$ & 0.912 & 0.863 \\
Male Annuitant & & 0.893 \\
\hline \hline
\end{tabular}

Note: Baseline survival probability is for a 58 year old female annuitant with a nominal, non-guaranteed, annual payment, single life annuity purchased in 1981 and paying the mean initial annual annuity payment for the voluntary market. Other rows reflect the probability of survival until age 75 for an annuitant who has the baseline characteristics and the baseline annuity, except for the change noted in the first column. 
TABLE 8: HEDONIC MODEL OF ANNUITY PRICING: THE EFFECT OF PRODUCT CHARACTERISTICS

\begin{tabular}{lrr}
\hline \hline & COMPULSORY MARKET & VOLUNTARY MARKET \\
\hline INDEX-LINKED & $0.096^{* * *}$ & $0.046^{* * *}$ \\
& $(0.004)$ & $(0.007)$ \\
ESCALATING & $0.004 *$ & $-0.032^{* * *}$ \\
& $(0.002)$ & $(0.005)$ \\
GUARANTEED & $-0.014^{* * *}$ & $-0.037^{* * *}$ \\
& $(0.0009)$ & $(0.002)$ \\
CAPITAL PROTECTED & & $-0.081^{* * *}$ \\
& & $(0.002)$ \\
PAYMENT (in £100s) & $----1)$ & $-0.0003 * * *$ \\
& $-0.002^{* * *}$ & $(0.00003)$ \\
PAYMENT Squared (in £100s) & $(0.00003)$ & $5.31 \mathrm{e}-07^{* * *}$ \\
Sample Size & $2.56 \mathrm{e}-06^{* * *}$ & $(8.78 \mathrm{e}-08)$ \\
\hline \hline
\end{tabular}

Note: Coefficient estimates are from linear regressions of price, defined as 1-Money's Worth, on product characteristics. Regressions include indicator variables for five-year intervals of age at time of annuity purchase, year of annuity purchase, gender of annuitant, and frequency of annuity payments. Standard errors are in parentheses. The omitted category for the "tilt" dummies (index-linked and escalating) is nominal annuities. The omitted category for the guarantee feature dummies (guaranteed and capital protected) is not guaranteed and not capital protected. $*, * *$, and $* * *$ denote statistical significance at the $10 \%, 5 \%$, and $1 \%$ levels, respectively. 